\title{
Critical analysis of stability and performance of organometal halide perovskite solar cells via various fabrication method (Review)
}

\author{
Suriati Suhaimi ${ }^{1}$, Zaliman Sauli ${ }^{1}$, Nor Azura Malini Ahmad Hambali ${ }^{2}$, Mohamad Halim Abd Wahid ${ }^{2}$, Vithyacharan \\ Retnasamy ${ }^{l}$, Mukhzeer Mohamad Shahimin ${ }^{3, *}$ \\ ${ }^{1}$ School of Microelectronic Engineering (SoME), Universiti Malaysia Perlis (UniMAP), Pauh Putra Main Campus, Jalan Arau- \\ Changlun, 02600 Arau, Perlis, Malaysia \\ ${ }^{2}$ Semiconductor Photonics \& Integrated Lightwave Systems (SPILS), Tun Abdul Razak Laser Laboratory (TAREL),School of \\ Microelectronic Engineering, Universiti Malaysia Perlis (UniMAP), Kampus Pauh Putra, Arau, Perlis, Malaysia. \\ ${ }^{3}$ Department of Electrical and Electronic Engineering, Faculty of Engineering, National Defence University of Malaysia (UPNM), \\ Kem Sungai Besi, 5700 Kuala Lumpur, Malaysia
}

\begin{abstract}
Organometal halide perovskite solar cells (Omh-PSCs) have attracted attention due to its unique electrical and optical properties. Ideally, the Omh-PSCs should remain free from degradation under normal operating conditions for several years, preferably tens of years. In order to produce high power conversion efficiency with low potential of degradation, different fabrication methods have been developed. The reported stability of perovskite films can vary significantly and reported to decay substantially up to $20 \%$ of its original performance. A thorough understanding of fabrication process upon the stability of the device is regarded as crucial to pave the way for future endeavors. This review summarized and highlighted the recent research of fabrication methods that gave an impact to the stability of perovskite devices.
\end{abstract}

\section{Introduction}

As a new type of photovoltaic technology, perovskite solar cell will become the ultimate low cost technology from now on [1]. A new generation of mixed organicinorganic halide perovskites hit the alluring prospects on both views; the overall cost to manufacture as well as the power conversion efficiencies [2]. Dye-sensitized solar cell (DSSCs) [3], organic solar cell [4] and hybrid solar cell [5] are emerging solar cell that made strides especially low cost fabrication technology using solution processing at low temperature and outlying large scale application. Perovskite solar cells initial research is correlated with DSSCs work, which is the perovskite materials that absorbed on mesoporous $\mathrm{TiO}_{2}$ employed as a dye-sensitizer in DSSCs. However, only half or less power conversion efficiencies (PCE) achieved as compared to the best commercial Si PV cells [6].

Most studies of light absorber layers are focusing on methylammonium (MA) lead halide $\mathrm{MAPbX}_{3}$ (X) $1 / 4$ halogen) and mixed-halide perovskites [7]. Recently, solar cells based on halide perovskites have been widely explored due to their high PCE, straightforward and low manufacturing cost [8]. Besides that, organometal halide perovskites have been attractive due to very excellent electrical and optical properties such as: (i) in mixed halide perovskite, the diffusion lengths is up to 1 [9], [10], (ii) good ambipolar (can be n- or p-type) transport of charge [11-12], (iii) absorption in the visible range is efficient [15-17], and (iv) synthesis method straightforward [16].

Over a few years under normal operating state, organometal halide perovskite solar cells (Omh-PSCs) must stay free from degradation, in order for Omh-PSCs to grow economically feasible which preferably tens of years. The assessment and indication of reliability of the devices are tough as the stability is correlated to the fading process of single solar cells [17]. Thus, for practical applications the stability is critical. The goal of this review is to look up a comprehensive view of the fabrication method that affects the stability of perovskite devices.

\section{Structure and Working Principle}

To assemble the perovskite solar cells, the various architectures of the device has been identified. General configuration of conventional PSC device is depicted in Fig.1 (a). Between a hole transporting material (HTM) and an electron transporting material (ETM) perovskite layer is sandwiched together with metal electrode substrates of indium tin oxide (ITO)/fluorine tin oxide 
(FTO). Structure of employing mesoporous metal oxide materials $\left(\mathrm{TiO}_{2}\right)$ and planar heterojunction structure without mesoporous materials [18-19] are two major architecture of perovskite solar cells devices .

Perovskite solar cells work by following processes: (i) the incident light absorbs by perovskite layer, (ii) ETMs and HTMs are extracted and transported the generated electron and hole, respectively as illustrated in Fig.1 (b). At the end, the electrode collected the charge carriers and forming complete cycle of the perovskite solar cells. Principally, the transportation and extraction of the hole and electron must be efficient. The highest occupied molecular orbital (HOMO) of HTMs must be greater than the maximum valence band (VBM), while, the minimum conduction band (CBM) of ETMs must be lower than the CBM of perovskite materials [15], which is important to be fully grasped.
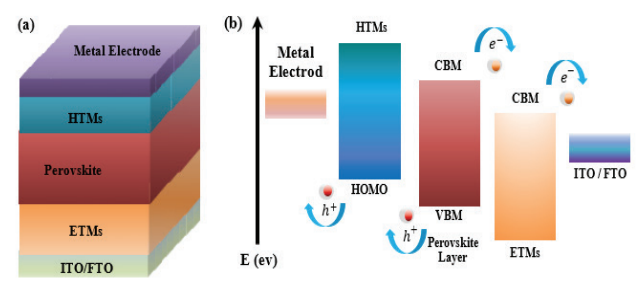

Fig.1. (a) A schematic illustration of perovskite device structure, (b) Working principle of ideal perovskite solar cells based on (a) [20].

\section{Fabrication Method}

Different methods that have been developed with regard to fabricate perovskite solar cell devices. There are two common methods that have been used to fabricate perovskite solar cells which are (i) one step coating and (ii) two step coating. However, on the side of producing high PCE with low potential of degradation, other additional method is introduced.

\subsection{Spin coating}

In order to grow quality perovskite thin films, a whole new field of technology has been developed. The one-step solution deposition which is used as direct deposition of perovskite precursor solution on top of mesoscopic, or planar oxide [7] is the most typical deposition procedure. The one-step spin coating has been extensively used in fabricating perovskite solar cells due to the easy fabrication method. However, the one-step spin coating in ambient air is not widely investigated because this approach crucially needs to be carried out in the glove box, in order to neglect the influence of moisture. [21]. Fig. 2 shown a schematic illustration of the fabrication in present of $\mathrm{TiO}_{2} / \mathrm{CH}_{3} \mathrm{NH}_{3} \mathrm{PbI}_{3}$ photovoltaic cells. Previous work are reported about the fabrication process in details except for the mesoporous $\mathrm{TiO}_{2}$ layer [22].

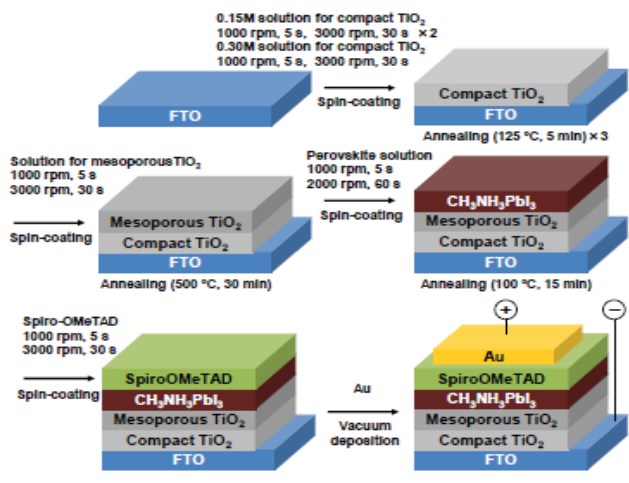

Fig.2. Schematic illustration of the fabrication $\mathrm{TiO}_{2} / \mathrm{CH}_{3} \mathrm{NH}_{3} \mathrm{PbI}_{3}$ photovoltaic cells using spin coating deposition method [22].

\subsection{Doctor Blade}

As been reported, the doctor blade method that fabricate in ambient air condition with planar structure has benefit in stability and photovoltaic performance of perovskite solar cell [23]. Based on the study, scanning electron microscope (SEM) shows the large domains of crystalline and the thin film formation on film substrate are uniformly covered, as depicted in Fig.3. The light absorption that produced the film prepared by using doctor blade technique proved that the dropping PV performance using spin coating technique in ambient air are related to the perovskite degradation [23].

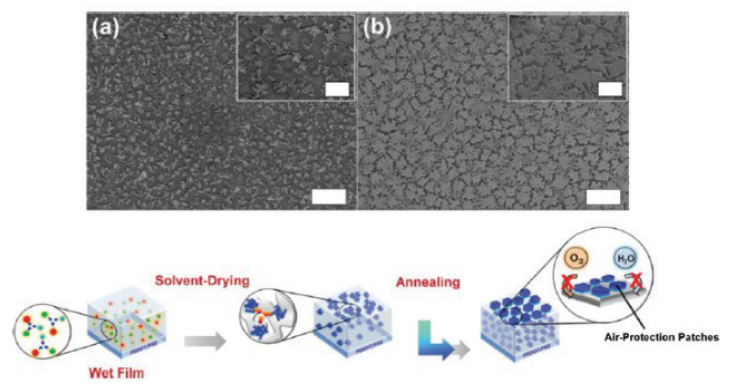

Fig.3. Perovskite thin films SEM image using (a) spin coating and (b) doctor blade method [23].

\subsection{Sequential Deposition}

Gratzel and co-workers was first used the sequential deposition method to deposit the absorber layer using $\mathrm{MAPbI}_{3}$ [24]. Generally, to achieve high reproducibility with an excellent performance of the perovskite, sequential deposition method is introduced to fabricate the perovskite sensitized mesoscopic solar cells. The best device for solution processed achieved PCE about 15\%, that conclude to be a new record as amongst the highest PCE for organic or hybrid inorganic solar cells [25]. Onestep or sequential deposition method are the common 
technique to deposit $\mathrm{MAPbI}_{3}$ perovskite thin films. As widely known, the sequential deposition method give first-string control over the growth of perovskite, and under near equilibrium condition the formation of crystalline might occur, as the resulting structure of $\mathrm{MAPbI}_{3}$ is as fascinating as one-step method [24].

\subsection{Hybrid Chemical Vapor Deposition}

Another method has also been used to deposit $\mathrm{MAPbI}_{3}$ film is hybrid chemical vapor deposition. The PCE about $11.8 \%$ obtained by using hybrid CVD and the same efficiency demonstrated although after 1100 hour the device stored in dark and dry $\mathrm{N}_{2}$ gas condition [26]. Preparation of perovskite film using vapor-based deposition technique is one of the promising approaches that gives an advantage for fabrication of large scale perovskite module fabrication and able to prevent fast reaction rate. Recently, a few works applying different vapor-assisted techniques have been reported, with the concern to the high-quality absorber layer that faces up the reduction of the response rate for a pin-hole-free layer [27].

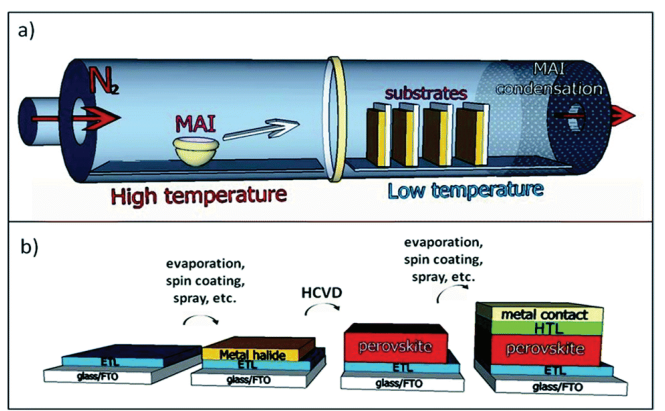

Fig.4. Perovskite synthesis using Hybrid CVS (a) Deposition of MAI substrate onto metal halide seeded in HCVD furnace. (b) The full solar cell structure of each layer fabricated in HCVD furnace. Overall layer of solar cell; (i) FTO layer, (ii) ETL, (iii) perovskite layer (iii) HTL and (iv) metal contact [26].

Fig.4 (a) illustrated one example of HCVD deposition process that used $\mathrm{PbCI}_{2}$ and MAI. The substrates FTO glass substrate with $\mathrm{TiO}_{2}$ compact layer pre-deposited with $\mathrm{PbCI}_{2}$ and MAI is loaded into the furnace with two separate temperature control zones. Fig.4 (b) shown a schematic diagram of overall cell and layers. The titanium dioxide on FTO thin film coated by spray pyrolysis is the electron transport layer (ETL) of the cell. The following layer is deposited with a metal halide layer and HCVD perovskite synthesis. A film of Spiro-MeOTAD is the hole transport layer (HTL) that spun onto the surface of perovskite followed by deposition via evaporation of top electrode with gold. By using hybrid CVD, the perovskite solar cells showed a stability higher to $11.8 \%$ which can encourage further study in the stability of perovskite especially under ambient conditions [26].

\subsection{Alternating Layer-by-Layer}

Alternating layer-by-layer vacuum deposition is one of the efficient method that has been formulated to fabricate perovskite solar cells. This method obtained $91 \%$ from its first value after 62 days being stored under an ambient condition with less degradation of $<9 \%$ [28]. The best efficiency achieved is $16.03 \%$ and average efficiency recorded by the planar device is $15.37 \%$ with a minimum standard deviation of $\pm 0.37 \%$ [28]. A factor of producing good stability was believed due to the dense formation of perovskite thin film with overall coverage surface that able to prevent penetration of moisture [29].
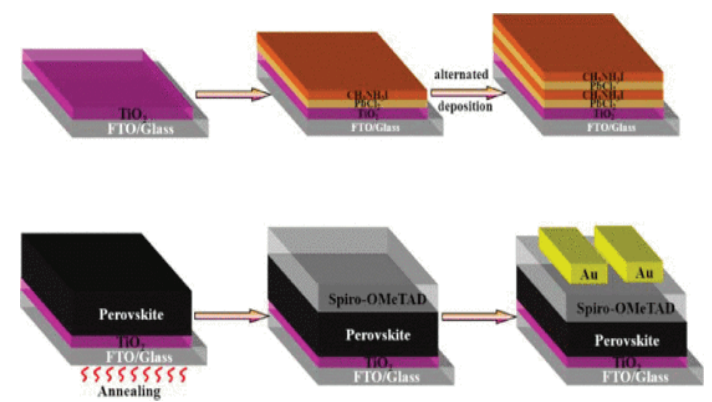

Fig.5. Process flow using alternated layer-by-layer vacuum deposition of perovskite solar cells [28].

A layer of $\mathrm{PbCI}_{2}$ was evaporated onto substrate/TCO/ $\mathrm{TiO}_{2}$ in a vacuum chamber via alternating precursor layer deposition as illustrated in Fig.5. The process begins with thermally sublimed the layer of $\mathrm{CH}_{3} \mathrm{NH}_{3}$ I onto the surface of the $\mathrm{PbCI}_{2}$ film, while the thickness of $\mathrm{CH}_{3} \mathrm{NH}_{3} \mathrm{I}$ film is controlled to secure the sufficient quantity for deposited $\mathrm{PbCI}_{2}$. To achieve high PCE, both of the processes are repeated until the acceptable thickness is generated. Then, the sample is annealed for 2 hours at temperature $20^{\circ} \mathrm{C}$ in a glove box condition. The sample color switched from taupe to dark color right after annealing, which reveals that perovskite film is formed through the interaction reaction between $\mathrm{PbCI}_{2}$ and $\mathrm{CH}_{3} \mathrm{NH}_{3} \mathrm{I}$. Consequently, both of the spiro-MeOTAD and gold which act as HTM and electrode were deposited on the perovskite film, separately [28]. Therefore, the fabrication process is found to be very reproducible.

\section{Effect of Fabrication Method}

The fabrication method is the one of the critical factors that gives an impact to the device stability. The reported stability of perovskite films is shown to vary quite significantly. In one case, perovskite is reported to decay as much as $20 \%$ substantially from its initial performance over the 6 days course in the $\mathrm{N}_{2}$ environment, and in others, it is reported to be stable. 
Table 1. Reliability of perovskite solar cells using various fabrication method.

\begin{tabular}{|c|c|c|c|c|c|}
\hline Fabrication Method & Composition/Structure & PCE (\%) & Reliability & Degradation & Ref. \\
\hline \multirow[t]{8}{*}{ Spin Coating } & $\begin{array}{c}\mathrm{FTO} / \mathrm{c}-\mathrm{TiO}_{2} / \\
\mathrm{Al}_{2} \mathrm{O}_{3} / \mathrm{MAPbI}_{3-\mathrm{x}} \mathrm{Cl}_{\mathrm{x}} / \mathrm{Au}\end{array}$ & $\sim 12$ & 1000 hour & & {$[30]$} \\
\hline & \multirow{3}{*}{$\begin{array}{c}\mathrm{FTO} / \mathrm{c}-\mathrm{TiO}_{2} / \mathrm{m}- \\
\mathrm{TiO}_{2} / \mathrm{MAPbI}_{3-\mathrm{x}} \mathrm{Cl}_{\mathrm{x}} / \mathrm{Au}\end{array}$} & 5.9 & $\begin{array}{l}\text { Without encapsulation. } 50 \% \text { of } \\
\text { initial PCC after } 5 \text { hour }\end{array}$ & Photocurrent degradation & \multirow[t]{3}{*}{ [30] } \\
\hline & & 7.1 & $\begin{array}{l}\text { With encapsulation, } 10 \% \text { of } \\
\text { initial PCC after } 5 \text { hour }\end{array}$ & & \\
\hline & & 6.2 & $\begin{array}{l}\text { With encapsulation and UV } \\
\text { Filter: No degradation }\end{array}$ & & \\
\hline & $\begin{array}{c}\mathrm{FTO} / \mathrm{c}-\mathrm{TiO}_{2} / \\
\mathrm{MAPbI}_{3-\mathrm{x}} \mathrm{Cl}_{\mathrm{x}} / \text { spiro } / \mathrm{Au}\end{array}$ & 10.2 & $\begin{array}{l}15 \text { days PCE dropped one } \\
\text { order of magnitude }\end{array}$ & $\begin{array}{l}\mathrm{PbI}_{2} \text { formation due to interaction } \\
\text { between perovskite with moisture based } \\
\text { on XRD measurement }\end{array}$ & {$[31]$} \\
\hline & $\begin{array}{c}\mathrm{ITO} / \mathrm{PEDOT}: \mathrm{PSS} / \\
\mathrm{MAPbI}_{3-\mathrm{x}} \mathrm{Cl}_{\mathrm{x}} / \mathrm{PC}_{61} \mathrm{BM} \\
/ \mathrm{C}_{60} \text {-bis } / \mathrm{Ag}\end{array}$ & 1.23 & Decomposed after 5 days & Perovskite degradation & {$[23]$} \\
\hline & $\begin{array}{c}\mathrm{FTO} / \mathrm{c}-\mathrm{TiO}_{2} / \mathrm{m}- \\
\mathrm{TiO}_{2} / \mathrm{MAPbI}_{3-\mathrm{x}} \mathrm{Cl}_{\mathrm{x}} / \text { spir } \\
\text { o/ } \mathrm{Au}(\mathrm{Precursor} \\
\left.\mathrm{PbCl}_{2}\right)\end{array}$ & 11.1 & 15 days, $20 \% \mu_{o}$ & $\begin{array}{l}\text { Lead precursor effect the stability } \\
\text { device, film morphology and cell } \\
\text { performance }\end{array}$ & {$[32]$} \\
\hline & $\begin{array}{c}\mathrm{FTO} / \mathrm{c}-\mathrm{TiO}_{2} / \mathrm{m}- \\
\mathrm{TiO}_{2} / \mathrm{MAPbI}_{3-\mathrm{x}} \mathrm{Cl}_{\mathrm{x}} / \text { spir } \\
\text { o/ } \mathrm{Au}\end{array}$ & 10.8 & $\begin{array}{l}15 \text { days: degradation is slightly } \\
\text { higher than cells with } \mathrm{PbCI}_{2} \\
\text { precursor }\end{array}$ & Different lead precursor & {$[32]$} \\
\hline \multirow[t]{2}{*}{ Blade Coating } & $\begin{array}{c}\text { ITO/PEDOT:PSS/ } \\
\mathrm{MAPbI}_{3-\mathrm{x}} \mathrm{Cl}_{\mathrm{x}} / \mathrm{PC}_{61} \mathrm{BM} / \\
\mathrm{C}_{60} \text {-bis } / \mathrm{Ag}\end{array}$ & 9.29 & PCE of $95 \%$ after 268 hour & $\begin{array}{c}\text { Enhance surface morphology, uniformity } \\
\text { of perovskite film and improve } \\
\text { crystalline size to be larger }\end{array}$ & {$[23]$} \\
\hline & $\begin{array}{l}\text { ITO/PEDOT:PSS/ } \\
\mathrm{CH}_{3} \mathrm{NH}_{3} \mathrm{PbI}_{\mathrm{x}} \mathrm{Cl}_{3-\mathrm{x}} / \\
\mathrm{PC}_{61} \mathrm{BM} / \mathrm{Bis}_{-} \mathrm{C}_{60} / \mathrm{Ag}\end{array}$ & 10.44 & $\begin{array}{l}\text { Maintain }>90 \% \text { of original } \\
\text { PCE after being stored for } 10 \\
\text { days in inert atmosphere }\end{array}$ & $\begin{array}{l}\text { Control humidity to enhance } \\
\text { performance }\end{array}$ & {$[33]$} \\
\hline Sequential Deposition & $\begin{array}{c}\mathrm{FTO} / \mathrm{TiO}_{2} / \\
\mathrm{CH}_{3} \mathrm{NH}_{3} \mathrm{PbI}_{3} / \\
\text { Spiro-MeOTAD } / \mathrm{Au}\end{array}$ & 13.0 & $\begin{array}{l}\text { Maintain }>80 \% \text { of initial PCE } \\
\text { after period of } 500 \text { hour. }\end{array}$ & $\begin{array}{l}\text { Decrease both fill factor and open circuit } \\
\text { voltage due to change of shunt resistance }\end{array}$ & {$[25]$} \\
\hline $\begin{array}{l}\text { Hybrid Chemical Vapor } \\
\text { Deposition }\end{array}$ & $\begin{array}{c}\mathrm{FTO} / \mathrm{c}-\mathrm{TiO}_{2} / \\
\text { perovskite/spiro/gold }\end{array}$ & 11.8 & 1100 hour: No degradation & $\begin{array}{l}\text { Perovskite reaches temperature above } \\
\qquad 160^{\circ} \mathrm{C}\end{array}$ & {$[26]$} \\
\hline $\begin{array}{l}\text { Alternating layer-by- } \\
\text { layer }\end{array}$ & $\begin{array}{c}\mathrm{FTO} / \mathrm{c}-\mathrm{TiO}_{2} / \\
\mathrm{MAPbI}_{3-\mathrm{x}} \mathrm{Cl}_{\mathrm{x}} / \text { spiro/ } \\
\text { gold }\end{array}$ & 16.03 & 62 days: $9 \%$ decrease in $\mu_{o}$ & $\begin{array}{l}\text { Fabrication of dense perovskite film } \\
\text { with overall coverage of surface that } \\
\text { prevents moisture penetration resulted in } \\
\text { high stability }\end{array}$ & {$[34]$} \\
\hline
\end{tabular}

As summarized in Table 1, the different fabrication methods with different structure and architecture of perovskite solar cell resulted in the different PCE which reflect the stability and reliability of the device. Based on the review, different fabrication process produced different stability and reliability of the device. Thus, its shows that the fabrication method also affected the PCE performance of the perovskite solar cells.

\section{Recommendation and Outlook}

The previous researcher have been investigating myriad of approaches in order to enhance the stability of the perovskite solar cells such as using different structures of the metal oxide films and different hole transport materials (HTM) that related to the hydrophobicity of the HTM, which is important to protect perovskite from atmospheric moisture. In this review, we critically analyzed the progress of various methods for fabrication PSCs and have discussed a number of degradation issues existed. However, a key challenge to fabricate PSCs, is the difficulty in comparing the stability testing results from the other group because of the different optimum condition that are utilized in each experiment such as humidity, temperature, and encapsulation technique. Therefore, for stability testing, it is necessary to standardize the required optimum condition. Regardless, to improve the stability of the PSC devices, the development of new technology in encapsulation is recommended. Specify standards testing devices need to be introduced such as device hysteresis, mechanical stability, stability under thermal stress and exposure to light, oxygen and moisture for every fabrication method. In summary, research on PSCs will eventually lead to the ultimate device that can rival the conventional siliconbased photovoltaics. However, it is highly critical to overcoming the stability issues that correlated with both the perovskite material and the fabrication method of the device to meet the required of long term stability. When the device is exposed to the high intensity of moisture or at high temperature, the perovskite solar cell shows the inevitable degradation. Thus, it is crucial to have a comprehensive understanding of the fabrication method that tangled in the deterioration of perovskite material to evolve robust strategy to resolve these issues.

FRGS (9003-00396), RACE (9017-00002), ERGS (901000004) and UPNM-STG (1. UPNM/2016/GPJP/4/ST/1) are acknowledged for the funding used for this investigation.

\section{References}

1. H. J. Snaith, J. Phys. Chem. Lett., 4, no. 21, pp. 36233630 (2013)

2. N.-G. Park, J. Phys. Chem. Lett., 4, no. 15, pp. 2423 2429, Aug. (2013)

3. S. Suhaimi, M. M. Shahimin, Z. A. Alahmed, J. Chyský, and A. H. \& Reshak, Int. J. Electrochem. Sci., 10, pp. 2859-2871 (2015)

4. R. Vairavan, M. M. Shahimin, and N. Juhari, 2011 IEEE Colloquium on Humanities, Science and 
5. A. H. Reshak, M. M. Shahimin, N. Juhari, and R. Vairavan, Curr. Appl. Phys., 13, no. 9, pp. 1894-1898 (2013)

6. P. K. Nayak and D. Cahen, Adv. Mater., 26, no. 10, pp. 1622-1628 (2014)

7. S. Casaluci et al., J. Power Sources, 297, pp. 504-510 (2015)

8. J. Qian, B. Xu, and W. Tian, Org. Electron. physics, Mater. Appl., 37, pp. 61-73 (2016)

9. $\quad$ S. D. Stranks et al., Science (80-. )., 342, no. 6156, p. 341 LP-344 (2013)

10. G. Xing et al., Science, 342, no. 6156, pp. 344-347, (2013)

11. E. Edri et al., 14, no. 2, pp. 1000-1004, (2014)

12. C. Zuo, H. J. Bolink, H. Han, J. Huang, D. Cahen, and L. Ding, Adv. Sci., 3, no. 7, p. 1500324-n/a (2016)

13. J. H. Noh, S. H. Im, J. H. Heo, T. N. Mandal, and S. Il Seok, Nano Lett., 13, no. 4, pp. 1764-1769, (2013)

14. G. E. Eperon, S. D. Stranks, C. Menelaou, M. B. Johnston, L. M. Herz, and H. J. Snaith, Energy Environ. Sci., 7, no. 3, pp. 982-988 (2014)

15. S. De Wolf et al., J. Phys. Chem. Lett., 5, no. 6, pp. 1035-1039, (2014)

16. H.-S. Kim et al., “ Sci. Rep., 2, p. 591, (2012)

17. T. A. Berhe et al., Energy Environ. Sci., 9, no. 2, pp. 323-356 (2016)

18. J. Shi et al., ACS Appl. Mater. Interfaces, 6, no. 12, pp. 9711-9718, (2014)

19. L. Liu et al., J. Am. Chem. Soc., 137, no. 5, pp. 17901793, (2015)

20. X. Tong, F. Lin, J. Wu, and Z. M. Wang, Adv. Sci., 3, no. 5, p. 1500201-n/a (2016)

21. G. Wang et al., RSC Adv., 6, no. 49, pp. 43299-43303 (2016)

22. T. Oku, T. Matsumoto, A. Suzuki, and K. Suzuki, Coatings, pp. 646-655 (2015)

23. J. H. Kim, S. T. Williams, N. Cho, C.-C. Chueh, and A. K.-Y. Jen, Adv. Energy Mater., 5, no. 4, p. 1401229$\mathrm{n} / \mathrm{a}(2015)$

24. H. Li et al., Sol. Energy, 126, pp. 243-251, (2016)

25. J. Burschka et al., Nature, 499, no. 7458, pp. 316-319, (2013)

26. M. R. Leyden, L. K. Ono, S. R. Raga, Y. Kato, S. Wang, and Y. Qi, J. Mater. Chem. A, 2, no. 44, pp. 18742-18745 (2014)

27. M. H. Li, P. S. Shen, J. S. Chen, Y. H. Chiang, P. Chen, and T. F. Guo, 2016 23rd International Workshop on Active-Matrix Flatpanel Displays and Devices (AMFPD). pp. 256-257 (2016)

28. D. Yang, Z. Yang, W. Qin, Y. Zhang, S. (Frank) Liu, and C. Li, J. Mater. Chem. A, 3, no. 18, pp. 9401-9405, (2015)

29. M. Shahbazi and H. Wang, Sol. Energy, 123, pp. 7487, (2016)

30. T. Leijtens, G. E. Eperon, S. Pathak, A. Abate, M. M. Lee, and H. J. Snaith, Nat. Commun., 4, pp. 1-8, (2013)

31. A. Mei et al., Science (80-. )., 345, no. 6194, p. 295 LP298 (2014)

32. F. K. Aldibaja, L. Badia, E. Mas-Marza, R. S. Sanchez, E. M. Barea, and I. Mora-Sero, J. Mater. Chem. A, 3, no. 17, pp. 9194-9200 (2015)

33. Z. Yang, C. Chueh, F. Zuo, J. H. Kim, P. Liang, and A. K. Jen, Advanced Energy Materials, 5 no. 13 (2015)

34. J. Yang, B. D. Siempelkamp, D. Liu, and T. L. Kelly, ACS Nano, 9, no. 2, pp. 1955-1963, (2015) 